\title{
STD-seventh national conference of the Indian Association
}

\author{
Report of the seventh national conference of the Indian Association for the study of sexually transmitted \\ diseases held at Bombay, India, on 26 and 27 February 1983
}

India is an immense country over twice the size of the European Economic Community. Its population, now more than 640 millions, accounts for a sixth of all mankind and is estimated to be increasing by nearly a million every four weeks. First impressions can be overwhelming and there appear to be too many people, too many animals, too many customs, too many gods; in fact, too much of everything. And yet there is only one India, a land of romance and dreams, of terrible poverty and great wealth, a free and democratic nation nearly overwhelmed with heat, poverty, and disease. Despite an illiteracy rate of over $65 \%$ and the existence of 14 major languages and 544 dialects, great progress has been made in industrial development, agriculture, science, and medicine. The diversity of India is tremendous and no statement about it is ever completely true.

\section{Background}

Throughout India the specialty of dermatovenereology is established in the hospitals and in private practice. In reality this means dermatology for both sexes and venereology for men. In many clinics and in private practice over $90 \%$ of the venereology patients are men, and contact tracing is not carried out in most cases. Some women with sexually transmitted diseases (STD) are seen by gynaecologists but communication between dermatovenereologists and gynaecologists about patients is non-existent. The exception is in Madras where dermatology and venereology are separate and the standards of practice at the world famous Institute of Venereology are an example to everyone.

There is a growing awareness of the importance of STD in India both in the medical profession and among the general public. Discussion of the diseases is

\footnotetext{
Address for reprints: Dr R D Catterall, James Pringle House, Middlesex Hospital, London WIN 8AA
}

Accepted for publication 19 March 1983 becoming easier and less embarrassing and some of the taboos and inhibitions are slowly disappearing. Standards of care for patients vary from place to place but the vast majority of centres are mainly concerned with male patients and prostitutes.

\section{Seventh national conference}

The seventh national conference of the Indian Association for the Study of Sexually Transmitted Diseases was held in the West End Hotel, Bombay, on 26 and 27 February 1983, and 110 delegates took part. The conference was opened by Dr Prabhakar $\mathrm{S}$ Pai, the mayor of Bombay, who said that it was fitting that such a conference should be held in this city with its fluid population and great mixture of races. The incidence of sexually transmitted diseases (STD) was certainly high in Bombay although accurate figures were not available.

Professor C N Sowmini, the president of the association, welcomed the new members and especially the overseas visitors who had come to support the conference. She stressed the fact that the incidence and range of the diseases was still increasing throughout the world and India was no exception to this trend.

The Silver Jubilee oration of the Institute of Venereology of Madras was given by $\mathrm{Dr}$ B A Daruvala, a senior and greatly respected physician, who reviewed the changes in diagnosis and treatment since the end of the second world war.

There followed a series of papers on the incidence of STD among industrial workers, coal miners, and residents in an urban slum community. There was also a symposium on the role of chlamydiae and mycoplasmas in genital inflammatory disease.

\section{VIRAL DISEASES}

Dr R D Catterall (London) gave the first guest lecture on sexually transmitted viral diseases and described in detail the new hepatitis B vaccine, which appears to be both effective and safe. He drew attention to the fact that this vaccine was the first type of immunisation that could prevent the eventual development of cancer, in the form of a primary liver cell carcinom There followed some discussion of sexuaj neuroses and impotence after STD and \&f the extent of knowledge about STD various sections of the community.

PPNG AND AIDS

The second guest lecture, on newer develo ments in sexually transmitted diseases, wh given by Dr William O Harrison of the United States Navy (San Diego). He described the deteriorating situation with regard to perd cillinase producing strains of gonocoge (PPNG) and the increase in the number of strains resistant to many antibiotics. TEe relatively new and often fatal AIBS (acquired immunodeficiency syndrom was discussed in detail. More than 800 cases and over 400 deaths had been reported California. The cause of the condition $\frac{2}{15}$ completely unknown, and many aspects of the disease are baffling. A reception and banquet were held at the Ward Room INSH, Ashwini, Colaba, and discussiक्ष continued far into the night.

The second day was characterised by series of papers on the relationship of ST to disorders of various systems, such as the cardiovascular, central nervous, and reprQductive systems. It was apparent that the late effects of syphilis were now rare India as elsewhere. A wide ranging ang often humorous paper on sexual myths uq masked by Dr Prakash Kothani was greaty appreciated by the audience.

\section{CHANGING PATTERNS OF STD} There followed the third guest lecture by R D Catterall on the changing patterns of STD in the world, in which it was pointed out that the old venereal diseases, syphilis gonorrhoea, and chancroid, provided onty $16 \%$ of the work of modern clinics and most cases were now due to infections with the newer sexually transmitted diseases, such ब\$ chlamydiae, genital herpes, hepatitis B, an more recently AIDS. 
The final session was devoted to interesting cases which ranged from leucomelanoderma of the palms and soles in secondary syphilis to gummatous ulceration of the tongue. It included a case of lymphangioma circumscriptum of the female genitalia and a case of unilateral orchitis in secondary syphilis.

\section{Future meeting}

There can be no doubt that the seventh national conference was a great success and the Indian Association for the Study of Sexually Transmitted Diseases is now firmly established as an important promoter of an annual conference for those interested in the diagnosis, treatment, and control of STD. It was attended by dermatovenereologists, venereologists, epidemiologists, physicians, microbiologists, and others. Its broadly based outlook, the quality of the communications, and the discussion reflect great credit on Indian medicine and on Dr J K Maniar the organiser.
At the annual general meeting of the IASSTD Dr B S Varma (Baroda) wa: elected president of the association and the next national conference will be held in Baroda in 1984. $R D$ Catteral
Vice-President, IUVDE 